\title{
Coffea canephora Bean Extract Induces NIH3T3 Cell Migration
}

\author{
Yessy Ariesanti ${ }^{1}$, Ferry Sandra $^{2}$, Bianda Claresta ${ }^{1}$, Livia Alvita $^{3}$ \\ ${ }^{1}$ Department of Oral and Maxillofacial Surgery, Faculty of Dentistry, Universitas Trisakti, Jl. Kyai Tapa No.260, Jakarta, Indonesia \\ ${ }^{2}$ Department of Biochemistry and Molecular Biology, Division of Oral Biology, Faculty of Dentistry, Universitas Trisakti, J1. Kyai Tapa No.260, \\ Jakarta, Indonesia \\ ${ }^{3}$ Faculty of Dentistry, Universitas Trisakti, Jl. Kyai Tapa No.260, Jakarta, Indonesia \\ *Corresponding author. E-mail: ferry@trisakti.ac.id
}

Received date: Feb 18, 2021; Revised date: May 20, 2021; Accepted date: May 24, 2021

\section{Abstract}

B ACKGROUND: Wound healing is an essential biological process that consists of sequential steps aimed at restoring the architecture and function of damaged cells and tissues. There are empirical evidences of using pure coffee bean powder as an alternative medicine in treating various types of wounds. However, there is limited data on coffee-induced wound healing, especially migration of cells. Therefore, current study was conducted to investigate the role of coffee extract in cell migration, especially fibroblast which is important for wound healing.

METHODS: Coffea canephora beans were prepared, extracted and added in the NIH3T3 cell culture in final concentration of $2.5 \%$ and $5 \%$. Then cytotoxicity test was performed using $\mathrm{Na}, 30$-[(phenylamino)-carbonyl]-3,4tetrazolium]-bis(4-methoxy-6-nitro) benzenesulfonic acid hydrate (XTT) assay. Meanwhile, cell migration test was

\section{Introduction}

Tooth extraction leaves a wound consisting of cortical bone and periodontal ligament causing the oral tissue to become inflamed. Wound healing is an essential biological process that consists of sequential steps aimed at restoring the architecture and function of damaged cells and tissues. (1) Wound healing is crucial after tooth extraction. Wound performed with scratch assay. All results were statistically analyzed.

RESULTS: The $2.5 \%$ or $5 \%$ Coffea canephora beans extract (CCBE)-treated NIH3T3 cell numbers were almost similar with the numbers of NIH3T3 cells in starvation medium merely. Meanwhile, $2.5 \%$ and 5\% CCBE showed significant decrease of the widths of scratched areas compared to starvation medium merely (ANOVA with LSD Post-hoc, $p=0.000$ ). After $24 \mathrm{~h}$ and $48 \mathrm{~h}$, the average widths of $2.5 \%$ and 5\% CCBE-treated scratched areas were $235.68 \pm 22.79$, $50.36 \pm 5.29,229.95 \pm 23.01,27.68 \pm 2.83$, respectively.

CONCLUSION: Since both $2.5 \%$ and $5 \%$ CCBE are potential in inducing migration of fibroblast (NIH3T3 cell) and do not induce cytotoxicity, the CCBE could be potential as an agent for wound healing.

KEYWORDS: coffee, Coffea canephora, NIH3T3, migration, cytotoxicity

Indones Biomed J. 2021; 2021; 13(2): 216-220 healing can be induced with several agents, including cells (2) and their factors (3). In wound healing process, fibroblasts are required as the source of the tissue. Fibroblasts have the ability to migrate/pull the wound edges so that the two wound edges are closer and attached. Fibroblasts also help the production of a replacement extracellular matrix (ECM) in re-epithelialization.(4)

Currently, most of the world's population is reapplying the concept of natural living, where plants are the 
preferred for treatments.(5) There are empirical evidences that Indonesians have long been using pure coffee bean powder as an alternative medicine in treating various types of wounds. A series of studies on coffee bean powder since the beginning of 2004 has shown that it can be used to treat various types of wounds, ranging from sharp scratches, burns to infected wounds.(6) In animal model, infected wound healing using coffee bean powder was shown to be superior than other traditional agents, such as honey.(7) Coffee bean powder has many useful ingredients, including alkaloids, saponins, flavonoids, phenolic compounds and chlorogenic acid.(8)

From several previous studies, it was estimated that flavonoids as anti-inflammatory, while saponins as antibiotics to inhibit bacterial growth in order to accelerate wound healing.(9) Coffee bean powder can be a potential agent for wound healing, and it is possible that there is a coffee ingredient that can induce the cell migration. However, there is limited data on coffee extract/ingredientinduced migration of cells. Therefore, current study was conducted to investigate the role of coffee extract/ingredient in cell migration, especially fibroblast which is important for wound healing.

\section{Methods}

\section{Coffea canephora Bean Extract (CCBE) Preparation}

Coffee (C. canephora) beans were cleaned, blended, mixed with $80 \%$ ethanol for 3 hours, macerated for 24 hours, filtered and evaporated. Resulted CCBE paste was diluted in starvation medium containing Dulbecco's Modified Eagle's Medium (DMEM) (Sigma-Aldrich, St. Louis, MO, USA) 2\% Fetal Bovine Serum (FBS) (Sigma-Aldrich) and $1 \%$ Penicillin-Streptomycin (Sigma-Aldrich), to reach final concentration of $2.5 \%$ and $5 \%$.

\section{NIH3T3 Cell Culture and Treatment}

NIH3T3 cells were cultured in complete medium containing DMEM, 10\% FBS and 1\% Penicillin-Streptomycin in 5\% $\mathrm{CO} 2,37^{\circ} \mathrm{C}$, humidified incubator. Upon reaching $80 \%$ confluence, NIH3T3 cells were dissociated with $0.05 \%$ Trypsin-EDTA and sub-cultured. After gaining enough cell numbers, the NIH3T3 cells were seeded in 96-well or 24well plate for further assays.

\section{Cytotoxicity Test}

Cytotoxicity test was performed using Na,30[(phenylamino)-carbonyl]-3,4-tetrazolium]-bis(4- methoxy-6-nitro) benzenesulfonic acid hydrate (XTT) Cell Proliferation Assay Kit (Cayman, Ann Arbor, MI, USA), to measure viable NIH3T3 cells as described previously.(10) Five thousand NIH3T3 cells were seed in 96-well plate overnight in complete medium. The cells were then rinsed with Phosphate-buffered Saline (PBS) and treated with starvation medium; starvation medium and $0.037 \% \mathrm{H}_{2} \mathrm{O}_{2}$; starvation medium and $2.5 \% \mathrm{CCBE}$; or starvation medium and 5\% CCBE for 24 or $48 \mathrm{~h}$. Treated cells were added with MTT reagent and incubated in a $37^{\circ} \mathrm{C}$ incubator for 4 hours. Proliferation was determined from the reduction of tetrazolium into insoluble formazan product by mitochondria of viable NIH3T3 cells. Absorbance was measured with a microplate reader at $595 \mathrm{~nm}$.

\section{Scratch Assay}

Scratch assay was performed to measure the cell migration. Fifty thousand NIH3T3 cells were seeded in 24-well plate for $24 \mathrm{~h}$ in complete medium. Then the scratch was made on each well using micropipette yellow tips to create $1 \mu \mathrm{m}$ gap of the cell culture. The cells were then rinsed with PBS and treated with starvation medium; starvation medium and $10 \%$ FBS; starvation medium and $2.5 \% \mathrm{CCBE}$; or starvation medium and 5\% CCBE for 24 or $48 \mathrm{~h}$. The gap width of each well was analyzed and documented under an Axio Vert inverted light microscope (Carl Zeiss, Oberkochen, Germany).

\section{Statistical Analysis}

Analysis of Variance (ANOVA) with Least Significant Difference Post-hoc was conducted to point out the difference of each group. The statistical analysis was performed using SPSS Statistics Version 20.0 (IBM Corp., Armonk, NY, USA). The significancy was set at $p$-value $<0.05$.

\section{Results}

\section{CCBE was Not Cytotoxic for NIH3T3 Cells}

In starvation medium, NIH3T3 cells grew $>3$-folds from 5,000 to 17,254 cells in $24 \mathrm{~h}$ and $>4$-folds from 5,000 to 20,834 cells in $48 \mathrm{~h}$ (Figure 1). Meanwhile addition of $0.037 \%$ $\mathrm{H}_{2} \mathrm{O}_{2}$, number of NIH3T3 cells were significantly (ANOVA, $p=0.000$ ) decreased in $24 \mathrm{~h}$, only 880 viable NIH3T3 cells remained. The cell numbers were continuously decreased in $48 \mathrm{~h}$. When the NIH3T3 cells were treated with $2.5 \%$ or $5 \%$ CCBE for 24 and 48 hours, the numbers of viable NIH3T3 cells were almost similar with the numbers of NIH3T3 cells in starvation. 


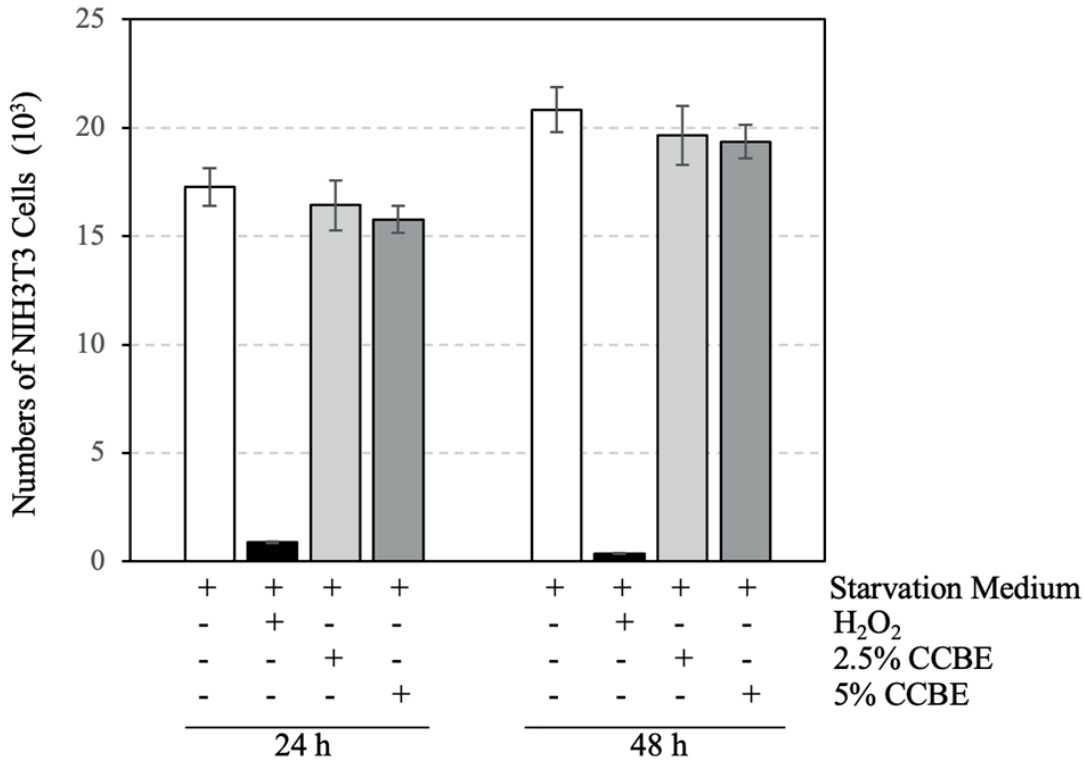

Figure 1. Numbers of CCBE-treated NIH3T3 Cells. NIH3T3 Cells were treated with starvation medium, $0.037 \% \mathrm{H}_{2} \mathrm{O}_{2}$, $2.5 \% \mathrm{CCBE}$ and $5 \% \mathrm{CCBE}$ for 24 and 48 hours. Cells numbers were counted with MTT assay as described in Methods. The results were gained from 3 independent experiments.

\section{CCBE Induced Migration of NIH3T3 Cells}

As shown in Figure 2, starvation medium had low induction of NIH3T3 cells migration. The widths of scratched areas remained large after $24 \mathrm{~h}(728.24 \pm 36.41 \mu \mathrm{m})$ and 48 h $(681.08 \pm 34.05 \mu \mathrm{m})$ (Figure 3). When 10\% FBS was added the migration was increased as shown by significant (ANOVA, $p=0.000$ ) (Table 1) decrease of the widths of scratched areas after $24 \mathrm{~h}(170.18 \pm 8.51 \mu \mathrm{m})$ and $48 \mathrm{~h}$ $(27.03 \pm 1.35 \mu \mathrm{m})$. Meanwhile $2.5 \%$ and $5 \%$ CCBE showed significant decrease of the widths of scratched areas. As shown in Figure 3, after $24 \mathrm{~h}$ and $48 \mathrm{~h}$, the average widths of $2.5 \%$ and $5 \%$ CCBE-treated scratched areas were $235.68 \pm 22.79, \quad 50.36 \pm 5.29, \quad 229.95 \pm 23.01, \quad 27.68 \pm 2.83$, respectively.

\section{Discussion}

Current results showed that treatment of 2.5\% CCBE and $5 \% \mathrm{CCBE}$ for $24 \mathrm{~h}$ and $48 \mathrm{~h}$ were not cytotoxic for NIH3T3 Cells. Numbers of $2.5 \%$ and $5 \%$ CCBE-treated viable NIH3T3 cells were almost similar with the numbers of

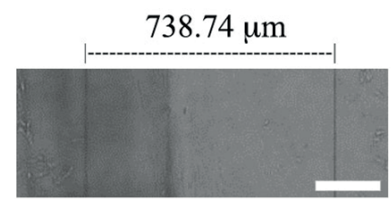

$175.08 \mu \mathrm{m}$

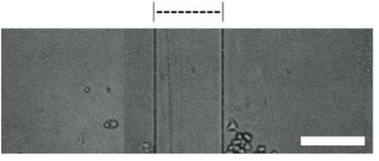

$232.43 \mu \mathrm{m}$

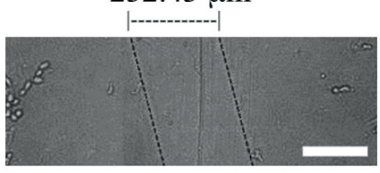

$231.98 \mu \mathrm{m}$

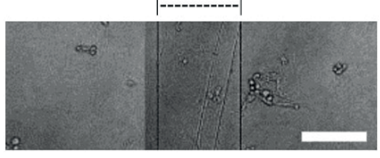

$24 \mathrm{~h}$
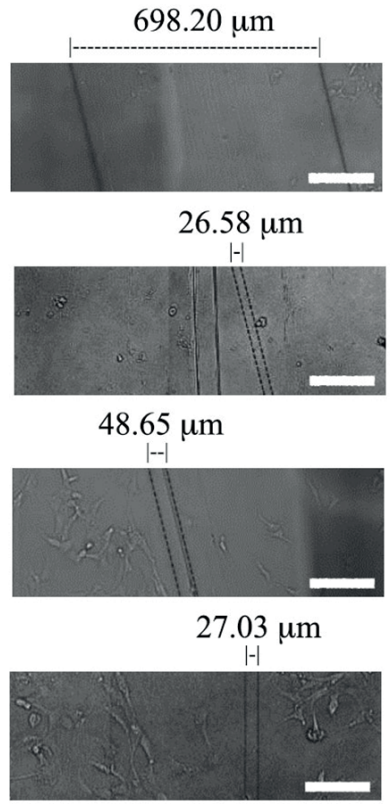

$27.03 \mu \mathrm{m}$

$5 \% \mathrm{CCBE}$

Starvation Medium

$10 \%$ FBS

$2.5 \% \mathrm{CCBE}$

$48 \mathrm{~h}$
Figure 2. Scratched areas of CCBEtreated NIH3T3 Cells. NIH3T3 Cell Culture were scratched and treated with starvation medium, $10 \% \mathrm{FBS}, 2.5 \%$ and $5 \% \mathrm{CCBE}$ for 24 and 48 hours as described in Methods. Figures were representative of typical results of 3 independent experiments. White bar: $150 \mu \mathrm{m}$. 


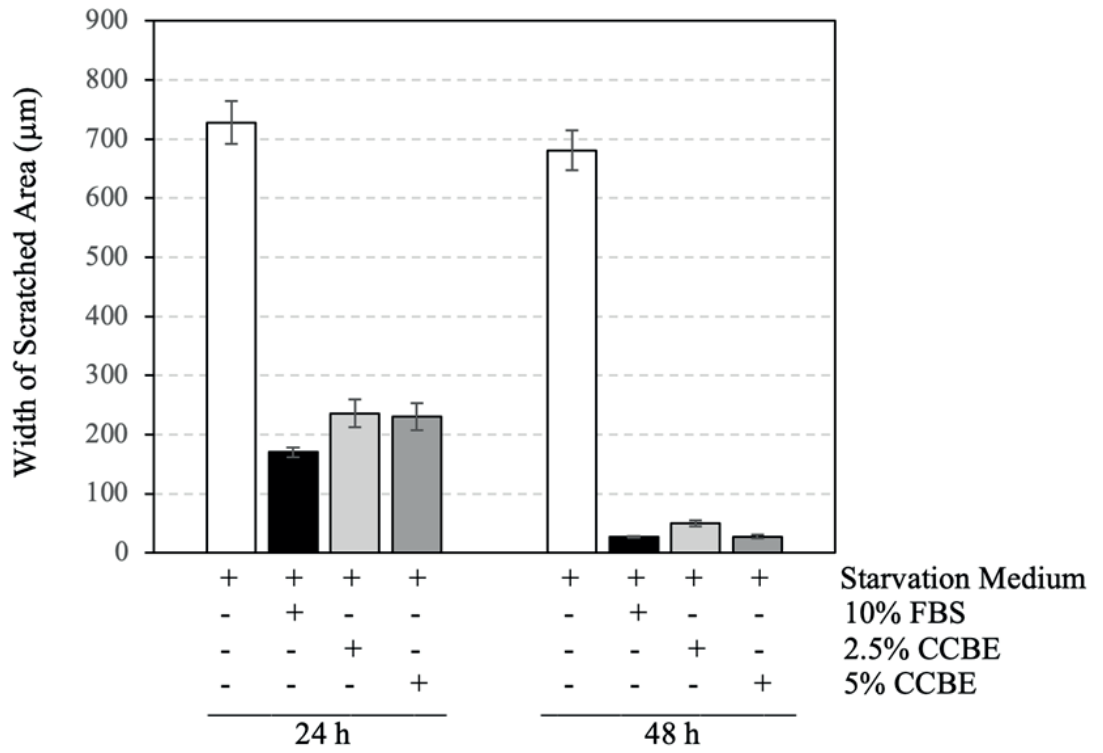

Figure 3. Average width of scratched areas of CCBE-treated NIH3T3 cells. NIH3T3 cell culture were scratched and treated with starvation medium, 10\% FBS, $2.5 \%$ and $5 \%$ CCBE for 24 and 48 hours. Width of scratched areas were counted as described in Methods. The results were gained from 3 independent experiments.
NIH3T3 cells in starvation medium merely at $24 \mathrm{~h}$ and 48 h. Hence, $2.5 \% \mathrm{CCBE}$ and $5 \% \mathrm{CCBE}$ could be potential for further assay. Similar in vitro study with fibroblast/NIH3T3 cell has not been reported, but a research in green coffee beans extract showed that $15 \%$ extract was not not cytotoxic, moreover it could induce proliferation of fibroblast.(11)

The basic migration cycle includes expansion, formation of stable attachments, translocation of cells, release of adhesions and retraction in other parts of the cell.(12) The migration is an important factor for tissue regeneration of various part of human.(10) In wound repairment, the purpose of this displacement is to bring the two sides of the open wound area together. The result of joining the two sides of the wound area (13), causing the formation of new connective tissue.(14) Migration of fibroblasts affect the wound healing process in wound area.(15,16) The migration of NIH3T3 cell/fibroblast was induced significantly by 2.5 and $5 \%$ CCBE, shown by reduction of scratched area widths. The migration was observed at $24 \mathrm{~h}$ treatment of 2.5 and $5 \% \mathrm{CCBE}$ and getting higher after $48 \mathrm{~h}$ treatment.
There were some reports related to wound healing-related cell migration induced by herbal extracts, such as Ocimum gratissimum extract (17) and Coccinia grandis extract.

Although CCBE has shown its potential in inducing cell migration, the molecular mechanism induced by CCBE should be further explored. With the advancement of molecular medicine, scientific evidence of medicine from natural resources could be pursued, so that all potential and mechanism could be disclosed. The are some reports based on genome-wide expression monitoring of genes by microarray analysis, for example Si-Jun-Zi decoction.(18) The results gave insight on its prescription and intestinal wound restitution. In regards to CCBE, further exploration of molecular mechanism should be pursued.

\section{Conclusion}

Since both $2.5 \%$ and $5 \% \mathrm{CCBE}$ are potential in inducing migration of fibroblast (NIH3T3 cell) and do not

Table 1. ANOVA with LSD Post-hoc analysis of the scratched assay results.

\begin{tabular}{ccccc}
\hline \multirow{2}{*}{ Group } & vs. & Group & $\mathbf{2 4} \mathbf{~ h}$ & $\mathbf{4 8}$ h \\
\cline { 4 - 5 } & & & 0. value \\
\hline Starvation Medium & $v s$. & $10 \% \mathrm{FBS}$ & 000 & 0.000 \\
Starvation Medium & $v s$. & $2.5 \% \mathrm{CCBE}$ & 0.000 & 0.000 \\
Starvation Medium & $v s$. & $5 \% \mathrm{CCBE}$ & 0.000 & 0.000 \\
$10 \% \mathrm{FBS}$ & $v s$. & $2.5 \% \mathrm{CCBE}$ & 0.001 & 0.033 \\
$10 \% \mathrm{FBS}$ & $v s$. & $5 \% \mathrm{CCBE}$ & 0.001 & 0.557 \\
$2.5 \% \mathrm{CCBE}$ & $v s$. & $5 \% \mathrm{CCBE}$ & 0.612 & 0.047 \\
\hline
\end{tabular}


induce cytotoxicity, the CCBE could be potential as an agent for wound healing. Further investigation should be explored.

\section{Acknowledgements}

The authors are thankful to ProSTEM Laboratory, Jakarta for facilitating this research.

\section{Authors Contribution}

YA and FS were involved in concepting and planning the research, FS and LA performed the data acquisition/ collection, BC and LA calculated the experimental data and performed the analysis, $\mathrm{BC}$ and LA drafted the manuscript and designed the figures, YA and FS aided in interpreting the results. All authors took parts in giving critical revision of the manuscript.

\section{References}

1. Meiliana A, Dewi MN, Wijaya A. Stem Cell Therapy in wound healing and tissue regeneration. Indones Biomed J. 2016; 8: 61-70.

2. Moenadjat Y, Merlina M, Surjadi CF, Kusnadi Y, Sandra F. The application of human umbilical cord blood mononuclear cells in the management of deep partial thickness burn. Med J Indones. 2013; 22: $92-9$

3. Dewi DAR, Sandra F. Conditioned media of human umbilical cord blood mesenchymal stem cell inhibits ultraviolet B-induced apoptosis in fibroblasts. Indones Biomed J. 2019; 11: 85-90.

4. Li B, Wang JH. Fibroblasts and myofibroblasts in wound healing: force generation and measurement. J Tissue Viability. 2011; 20: $108-20$.

5. Sandra F. Role of herbal extract in stem cell development. Mol Cell Biomed Sci. 2018; 2: 19-22.

6. Shetty V, Bertolami, CN. Peterson's Principle of Oral and
Maxillofacial Surgery in Wound Healing. Michael M, editor. 3rd Ed. Shelton: PMPH-USA; 2012.

7. Setyawan T, Yuwono HS, Andean R. Comparison on infected wound healing time, using coffee powder and honey in wistar rat. Int J Gen Med Phar. 2017; 6: 1-6.

8. Sugiono E, Wijaya A, Santoso A, Sandra F, Patellongi IJ, Yusuf I. Frequencies of CYP1A2 single nucleotide polymorphism in Indonesian and its effect on blood pressure. Indones Biomed J. 2018; 10: 297-302.

9. Affonso RC, Voytena AP, Fanan S, Pitz H, Coelho DS, Horstmann $\mathrm{AL}$, et al. Phytochemical composition, antioxidant activity, and the effect of the aqueous extract of coffee (Coffea arabica L.) bean residual press cake on the skin wound healing. Oxid Med Cell Longev. 2016; 2016: 1923754. doi: 10.1155/2016/1923754.

10. Sandra F, Oktaviono YH, Widodo MA, Dirgantara Y, Chouw A, Sargowo D. Endothelial progenitor cells proliferated via MEKdependent p42 MAPK signaling pathway. Mol Cell Biochem. 2015; 400: 201-6.

11. Humaryanto, Ave O Rahman. Effect of green coffee beans extract ointments for wound healing. J Kedokt Brawijaya. 2019; 30: 16974.

12. Trepat X, Chen Z, Jacobson K. Cell migration. Compr Physiol. 2012; 2: 2369-92.

13. Safferling K, Sütterlin T, Westphal K, Ernst C, Breuhahn K, James $\mathrm{M}$, et al. Wound healing revised: a novel reepithelialization mechanism revealed by in vitro and in silico models. J Cell Biol. 2013; 203: 691-709.

14. Oktaviono YH, Al-Farabi MJ, Suastika LOS, Hartono F, Dirgantara Y, Sandra F. Preliminary study: Purple sweet potato extract seems to be superior to increase the migration of impaired endothelial progenitor cells compared to 1-ascorbic acid. Sci Pharm. 2019; 87: 16. doi: 10.3390/scipharm 87030016 .

15. Freshney R. Culture of Animal Cells a Manual Basic Technique. 5th ed. New York: Wiley; 2005.

16. Khatun Z, Nishimura N, Kobayashi D, Hazama A. Cesium suppresses fibroblast proliferation and migration. Fukushima J Med Sci. 2020; 66: 97-102.

17. Chang SH, Liu JY, Hsiao MW, Yang HL, Wang GW, Ye JC. Protective effects of Oocimum gratissimum aqueous extracts on $\mathrm{HaCaT}$ cells against UVC-induced inhibition of cell viability and migration. Int J Med Sci. 2021; 18: 2086-92.

18. Liu L, Han L, Wong DY, Yue PY, Ha WY, Hu YH, et al. Effects of Si-Jun-Zi decoction polysaccharides on cell migration and gene expression in wounded rat intestinal epithelial cells. Br J Nutr. 2005; 93: 21-9. 